\title{
Tre decennier av populistiska radikalhögerpartier i Västeuropa
}

\section{Cas Mudde}

SAMMANDRAG: Den populistiska radikalhögern är den mest framgångsrika partifamiljen i Västeuropa under efterkrigstiden. Från forskarhåll och i medierna har det länge varnats för det ökande inflytandet från de populistiska radikalhögerpartierna, vad man kallar en högervridning av den europeiska politiken, men det finns få tydliga empiriska belägg för utvecklingen. Cas Muddes artikel ger en övergripande analys av den populistiska radikalhögerns påstådda inflytande på folket, partierna, politiken och styrelseformerna i Västeuropa. Hans slutsatser kan beskrivas som lugnande. Partiernas påverkan är i stort sett begränsad till frågor om invandring och integration, och även i detta sammanhang bör de snarare ses som katalysatorer än initiativtagare. Trots en begränsad inverkan finns det fortfarande skäl att tro att populistiska radikalhögerpartier skulle kunna få mer inflytande inom en snar framtid. Men även om partierna osannolikt nog skulle lyckas bli stora aktörer i västeuropeisk politik, förefaller det inte troligt att detta skulle leda till en genomgripande förändring av det politiska systemet. Den populistiska radikalhögern är, menar Mudde, inte en normal patologi inom den europeiska demokratin, utan relation till dess grundläggande värderingar, utan snarare en patologisk normalitet, som strävar efter att radikalisera mainstreamvärderingar.

NYCKELORD: radikal höger; populism; politiska partier; invandring; Västeuropa; kris.

PUBLICERINGSHISTORIK: Översättning av artikeln "Three decades of populist radical right parties in Western Europe: So what?” från European Journal of Political Research, volym 52, nr I 2013 (DOI: http://dx.doi.org/IO.IIII/j.I475-6765.20I2.02065.x).

CAS MUDDE är docent i statsvetenskap vid University of Georgia.

E-POSTADRESS: mudde@uga.edu

\section{FÖRSLAG PÅ KÄLLANGIVELSE:}

Mudde, Cas (20I6) "Tre decennier av populistiska radikalhögerpartier i Västeuropa”, i Det vita fältet III. Samtida forskning om högerextremism, specialnummer av Arkiv. Tidskrift för sambällsanalys, nr 5, s. 67-9I. DoI: http://dx.doi.org/IO.I3068/2000-6217.5.3

(C) original: European Consortium for Political Research 2012

(C) svensk version: Cas Mudde/Arkiv förlag \& tidskrift 20 I6 (publicerad I8 april 20I6)

Artikeln distribueras enligt en upphovsrättslicens från Creative Commons:

Erkännande-Ickekommersiell-IngaBearbetningar 3.o Unported, som medger fri ickekommersiell användning och spridning i oförändrat skick så länge källan anges. 
Arkiv. Tidskrift för samhällsanalys är en sakkunniggranskad vetenskaplig tidskrift för samhällsvetenskap och historia. Samtliga artiklar publiceras fritt tillgängliga på:

$$
\text { www.tidskriftenarkiv.se }
$$

(beständig länk, DoI: http://dx.doi.org/IO.I3068/2000-62I7)

Den här artikeln finns tillgänglig i följande format:

PDF \& HTML: via beständig länk, DOI: http://dx.doi.org/IO.I3068/2000-62I7.5.3

EPUB: ingår i e-boksutgåva av numret, ISBN: 978 9I 79242763

TRYCK: ingår i bokutgåva av numret, ISBN: 978 9I 7924277 O

Grafisk utformning och sidnumrering är identisk i pdf och tryck.

Samtliga artiklar i nr 5 (20I6), Det vita fältet III. Samtida forskning om högerextremism, nås via beständig länk, Dor: http://dx.doi.org/IO.13068/2000-6217.5

Redaktion för numret: Mats Deland, Paul Fuehrer, Fredrik Hertzberg och Thomas Hvitfeldt

Arkiv. Tidskrift för samhällsanalys ISSN: 2000-62I7 (för elektronisk resurs) ISSN: 2000-6225 (för tryckta nummer)

ges ut av

Stiftelsen Arkiv för främjande och spridning av samhällsvetenskaplig och historisk forskning

genom

Arkiv förlag \& tidskrift

Box 1559

SE-22I OI Lund

ВESÖK: L Gråbrödersg 3 c, ipg

TEL: 046-I3 3920

ARKIV FÖRLAG: arkiv@arkiv.nu·www.arkiv.nu

TIDSKRIFTEN ARKIV: red@tidskriftenarkiv.se · www.tidskriftenarkiv.se

ANSVARIg UTGIVARE \& CHEFREDAKTÖR: Sven Hort

ADMINistrativ RedAKTÖr: David Lindberg

ReDAKTörer: Paavo Bergman, Lisa Kings, Zhanna Kravchenko 


\title{
Tre decennier av populistiska radikalhögerpartier i Västeuropa
}

\author{
CAS MUDDE
}

\section{Inledning}

Det är nu över fyrtiofem år sedan Seymour Martin Lipset och Stein Rokkan publicerade sin berömda "fryshypotes" ("freezing hypothesis"), som beskrev utvecklingen av det västeuropeiska partisystemet (Lipset \& Rokkan 1967). Trots att denna tes i princip vederläggs varje gång ett nytt parti når stora framgångar $\mathrm{i}$ ett val, eller ett gammalt parti förlorar, så hävdade Peter Mair (1997, s. 3) så sent som i mitten av 1990-talet att denna hypotes "i stort sett är giltig, åtminstone fram till nu”. Men mycket har förändrats sedan Mair skrev dessa ord. Av särskild vikt för denna artikel är det faktum att "populistiska radikalhögerpartier" inte bara ökat sitt väljarstöd och sin närvaro i parlamenten i hela Västeuropa, utan att de också slutligen har kommit in i nationella regeringar.

Alltsedan den så kallade tredje vågen av radikal höger blygsamt inleddes för tre decennier sedan (Beyme 1988), har ett flertal kommentatorer varnat för dess negativa inverkan på europeisk demokrati. Tillfrågad av Frankfurter Allgemeine Zeitung angående vilka de största riskerna

Texten presenterades ursprungligen som en Stein Rokkan-föreläsning vid European Consortium for Political Research's Joint Sessions of Workshops i Antwerpen i Belgien II april 20I2, och publicerades sedan som "Three Decades of Populist Radical Right Parties in Western Europe: So What?" i European Journal of Political Research, volym 52, nr I 2013 (http://dx.doi.org/IO.IIII/j.I475-6765.20I2.02065.x). Den publiceras här efter vänligt tillmötesgående av författaren och tidskriften. 
för Europa är, svarade EU:s dåvarande president Herman Van Rompuy, med en direkt hänvisning till partiet Vlaams Belang i sitt eget hemland Belgien: "den största faran är populismen" (Stabenow 20I0). Detta sades 20ı, då den största ekonomiska krisen under hela efterkrigstiden var som mest påtaglig.

Känslan av ökande fara och inflytande från den populistiska radikalhögern finner vi dock inte endast hos de politiska medtävlarna. I medierna hittar vi många artiklar som varnar för att den populistiska högern är "på framväxt" (från The Guardian, 6 november 20II), eller - än mer dramatiskt - "på marsch" (The Economist, 17 mars 20IO), vilket anses leda till att "Europa glider högerut" (Los Angeles Times, 23 april 2002) och att "Europa [har] ett extremhögerproblem" (CNN, 26 juli 20II).

Den upplevda betydelsen av de populistiska radikalhögerpartierna kommer också till uttryck i en oproportionerligt stor akademisk uppmärksamhet mot dessa partier. Det är tämligen svårt att hitta (icke-tyska) studier av den populistiska radikalhögern skrivna före 1990, men i dag finns det mer än ett hundratal forskare spridda över hela världen som arbetar med denna fråga, och de producerar fler artiklar och böcker om denna specifika "partifamilj" än forskningen om de övriga partifamiljerna tillsammans.

De flesta forskare verksamma inom forskningsfältet är ense om att den populistiska radikala högern i dag är en viktig maktfaktor inom europeisk politik. De pekar ut förekomsten av en uppsjö förändringstendenser, vilka ibland antas orsaka den gradvisa förflyttning populistiska radikalhögerpartier gjort från den europeiska politikens marginaler in mot dess mitt, och ibland antas vara en konsekvens av samma rörelse. Bland dessa tendenser finns alltifrån politiskt missnöje och omfattande rasistiskt våld bland "vanligt folk" till en tilltagande dominans av högerorienterade diskurser och politiska prioriteringar hos eliten. I de flesta fall är beläggen för denna utveckling i bästa fall anekdotisk, och genomgående misstas korrelation för kausalitet. I rättvisans namn bör det tilläggas att många av dessa effekter är svåra att styrka ens i teorin, eftersom de hänvisar till indirekta effekter eller bygger på empiri som inte existerar.

Många politiker och röster i mediebranschen beskriver inflytandet från de populistiska radikalhögerpartierna som en högervridning (på 
nederländska verrechtsing) inom europeisk politik. Dessa partier har, hävdar man, drivit den europeiska politiken mot höger, genom att direkt eller indirekt påverka vad som kommer upp på den politiska agendan. Till exempel skrev Martin Schulz, som leder den socialistiska gruppen i EU-parlamentet, att det som oroar honom mest med den populistiska och radikala högerns framväxt inte är det högerextrema våldet, utan "det ihållande och ständigt pågående raserandet av tabun som gör extremhögerns ideologi respektabel, under täckmanteln av demokratisk legitimitet" (Schulz 20II, s. 30).

\section{Närvaron av populistiska radikalhögerpartier}

Populistiska radikalhögerpartier har en gemensam kärnideologi som består av en tro på inföddas principiella och generella företräde framför invandrade (engelskans "nativism"), en auktoritär syn på politiskt ledarskap och populism (se Mudde 2007). Vad gäller vissa partier, som till exempel franska Nationella fronten, är de flesta helt eniga om att de tillhör denna partifamilj; i andra fall är oenigheten betydligt större. Tabell I (nedan) tillhandahåller en överblick över populistiska radikalhögerpartiers valresultat i Västeuropa mellan I980 och 20II, med en lista över partiernas bästa och senaste resultat under denna period. Oaktat en del anmärkningsvärt sena och höga resultat, är det likväl tydligt att "den tredje vågen” av radikal högerpopulism inte riktigt har nått alla Europas stränder. I själva verket är partierna representerade i endast hälften av Västeuropas sjutton parlament.

Särskilt insiktsfullt är att jämföra de populistiska radikalhögerpartierna med den gröna partifamiljen, som ofta hålls för att vara en spegelbild av de förstnämnda. I tabell 2 (nedan) kan vi se att de populistiska radikalhögerpartierna inte har ett påtagligt större genomsnittligt resultat i nationella val än de gröna. Mer förvånande är kanske att medan de är lite mer lyckosamma i val, så är de mindre lyckosamma när det gäller att komma i regeringsställning, även om detta håller på att förändras. Sedan I980 har gröna partier suttit med i tio regeringar, medan populistiska radikalhögerpartier endast har suttit med i åtta. Likväl förefaller det som att 2000-talets första decennium var det mest lyckosamma årtiondet för 
de populistiska radikalhögerpartierna, medan I990-talet utgjorde höjdpunkten för de gröna vad avser deltagande i regeringar. Därtill kommer att populistiska radikalhögerpartier har agerat som stödpartier för en rad minoritetsregeringar.

På det hela taget förefaller det som att populistiska radikalhögerpartier i regeringsställning utgör något av en sällsynthet. Av de dryga 200 regeringar som verkat i Västeuropa 1980-20I2 finner vi sådana partier i endast åtta av dem. Inte i något fall var de ledande regeringsparti (se tabell 3 nedan). Endast i tre västeuropeiska länder (Österrike, Italien och Schweiz) har det funnits majoritetsregeringar som inkluderat populistiska radikalhögerpartier, ${ }^{I}$ och i ytterligare två länder (Danmark och Nederländerna) har det funnits minoritetsregeringar med deras stöd; likväl är trenden uppåtgående. Under 1980-talet fanns ingen sådan regering, och under 1990-talet endast en (Berlusconis första regering), men under 2000-talets första decennium har vi kunnat se sju majoritetsregeringar och tre minoritetsregeringar. Icke desto mindre finner vi i dag endast en majoritetsregering - i Schweiz - där ett populistiskt radikalhögerparti ingår, och endast ett fall - Nederländerna - där ett sådant parti officiellt stödjer en minoritetsregering.

Det här betyder ändå inte att populistiska radikalhögerpartier inte har betydelse för västeuropeisk partipolitik; enbart det faktum att dessa partier är den mest framgångsrika nya partifamiljen i Europa under efterkrigstiden talar mot en sådan enkel slutsats. Men samtidigt bör dessa sakförhållanden göra oss skeptiska till alltför alarmistiska påståenden om den populistiska radikalhögerns inflytande på västeuropeisk politik.

\section{Att bedöma populistiska radikalhögerpartiers inflytande}

Många känner sig manade att bedöma den populistiska radikala högerns inflytande. Icke desto mindre har vi hitintills sett relativt få vetenskapliga studier som verkligen undersöker detta antagande på ett systematiskt och empiriskt sätt. Därtill kommer att många studier endast undersöker en

I. Laikós Orthódoxos Synagermós (LAOS, "Folklig ortodox samling”), var del av den grekiska regeringen under bara två månader runt årsskiftet 20II-20I2. Så snart den nya regeringen måste ta sitt första större beslut - det vill säga, gå med på en europeisk finansiell uppgörelse - avvek LAOS-ministrarna från partilinjen och sparkades ut ur partiet. 


\section{Tabell I. De viktigaste populistiska radikalhögerpartiernas bästa och senaste valresultat $i$ Västeuropa, I980-20II}

\begin{tabular}{|c|c|c|c|}
\hline Land & Parti & $\begin{array}{c}\text { Bästa } \\
\text { valresultat }\end{array}$ & $\begin{array}{c}\text { Senaste } \\
\text { valresultat }\end{array}$ \\
\hline \multirow[t]{2}{*}{ Belgien } & Vlaams Belang (VB) & $\mathrm{I} 2, \mathrm{O}$ & 7,8 \\
\hline & Front nouveau de Belgique (FNB) & 2,3 & - \\
\hline Danmark & Dansk folkeparti (DF) & $\mathrm{I} 3,8$ & $\mathrm{I} 2,3$ \\
\hline Finland & $-^{*}+1$ & - & - \\
\hline Frankrike & Nationella fronten (Front National, FN) & 15,3 & 4,3 \\
\hline Grekland & Laikós Orthódoxos Synagermós (LAOS) & 5,6 & 5,6 \\
\hline Irland & - & - & - \\
\hline Italien & Lega Nord (LN) & IO, I & 8,3 \\
\hline Luxemburg & National Bewegung (NB) & 2,6 & - \\
\hline Nederländerna & Frihetspartiet (Partij voor de Vrijheid, PVV) & 15,5 & 15,5 \\
\hline Norge & $-^{*}$ & - & - \\
\hline Portugal & Partido Nacional Renovador (PNR) & 0,3 & 0,3 \\
\hline Schweiz & Schweiziska folkpartiet (Schweizerische Volkspartei, SVP) & 28,9 & 26,6 \\
\hline Spanien & Frente Nacional (FN) & 0,5 & 0,0 \\
\hline Storbritannien & British National Party (BNP) & $\mathrm{I}, 9$ & $\mathrm{I}, 9$ \\
\hline Sverige & Sverigedemokraterna (SD) & 5,7 & 5,7 \\
\hline Tyskland & Die Republikaner (REP) & $2, \mathrm{I}$ & 0,4 \\
\hline \multirow[t]{2}{*}{ Österrike } & Bündnis Zukunft Österrich (BZÖ) & IO,7 & IO,7 \\
\hline & Frihetspartiet (Freiheitliche Partei Österreich, FPÖ) & 26,9 & 17,5 \\
\hline
\end{tabular}

* Enligt Muddes definition är varken Sannfinländarna eller Fremskrittspartiet (liksom UKIP) att betrakta som populistiska radikalhögerpartier då han inte ser "nativism" (föreställningen om inföddas principiella och generella företräde framför invandrare) som en central del av deras ideologier. Red. anm.

Källa: Manuel Álvarez-Riveras webbplats Election Resources on the Internet: Western Europe, http://electionresources.org/western.europe.html.

enda aspekt av dessa påstådda effekter, nämligen invandringspolitiken, och tenderar att använda ett tämligen begränsat och implicit teoretiskt ramverk i vilket regeringspartier antas vara om inte den enda så i alla fall den allsmäktiga policyformulerande aktören. Dessutom står många forskare inför viktiga fallstudie- och dataproblem: vi har relativt få exempel på stora populistiska radikalhögerpartier, och än färre exempel på sådana partier i regeringsställning, och i många centrala avseenden saknar vi till- 
förlitliga och jämförbara data för jämförelser mellan olika länder och tidpunkter. Det gäller till exempel hur opinioner formas och attityder förändras. De flesta studier är sålunda begränsade till att gälla ett fåtal länder eller politikområden, eller genom användandet av problematiska data. Detta gäller tyvärr även för denna artikel, olyckligtvis, och den kan därför endast betraktas som en första ansats till en mer omfattande bedömning av de populistiska radikalhögerpartiernas inflytande.

Jag kommer här att försöka fastställa den populistiska radikalhögerns inflytande i västeuropeisk politik genom att belysa fyra aspekter: folket, partierna, politiken och styrelseformerna. Jag kommer att presentera min analys i just denna ordning därför att jag håller för troligt att den populistiska radikalhögern i första hand påverkar folket, vilket leder till en respons från de etablerade partierna (oroade för konkurrens i de allmänna valen), vilket sedan i sin tur leder till en utveckling av nya politiska linjer eller handlingsprogram, och eventuellt till en förändring av hela det politiska systemet.

\section{Folket}

Enligt "högervridningsteorin" har de populistiska radikalhögerpartiernas framgångar haft konsekvenser för hur människor i Europa tänker kring politik. Charles Westin hävdar till exempel (2003, s. I23) att "när protestpartier som Vlaams Belang och Nationella fronten får mer och mer röster, så förskjuts den allmänna opinionens gravitationscentrum på ett påtagligt sätt mot höger”. Kort sagt: genom sin förmåga att "sätta agendan" (Minkenberg 200I) har populistiska radikalhögerpartier ökat väljarnas benägenhet att positionera sig i och prioritera den populistiska radikalhögerns hjärtefrågor, som invandring, brottslighet, korruption och europeisk integration.

Det är förvisso tydligt att populistiska radikalhögerpartier har vunnit på det faktum att sociokulturella frågor fătt en ökande betydelse i västeuropeisk politik under de senaste decennierna, men denna "tysta revolution" (Inglehart 1977) var en händelse som i stort sett föregick dessa partiers genombrott. Om vi fokuserar på de specifika politiska frågor jag nyss nämnt, kan vi se att de flesta av dem, framför allt invandringsfrågan, har hamnat mer i fokus under de senaste trettio åren. Likväl kan denna förskjutning mycket väl bli en högst flyktig företeelse, och verkar 


\section{Tabell 2. Genomsnittliga valresultat och regeringsmedverkan for de gröna partierna och de populistiska radikalhögerpartierna i Västeuropa (per decennium) I980-2009}

\begin{tabular}{lccc} 
& $1980-1989$ & $1990-1999$ & $2000-2009$ \\
\hline Genomsnittliga valresultat & & & \\
$\quad$ Populistiska radikalhögerpartier & I,7 & 4,8 & 5,9 \\
$\quad$ Gröna partier & I,9 & 3,2 & 4,7 \\
Regeringsmedverkan & & & \\
$\quad$ Populistiska radikalhögerpartier & 0 & I & 7 \\
Gröna partier & 0 & 7 & 3 \\
\hline
\end{tabular}

Källa: Uppgifterna för de gröna partierna kommer från Europeiska gröna partiets officiella webbplats: http://europeangreens.eu/menu/elections/election-results.

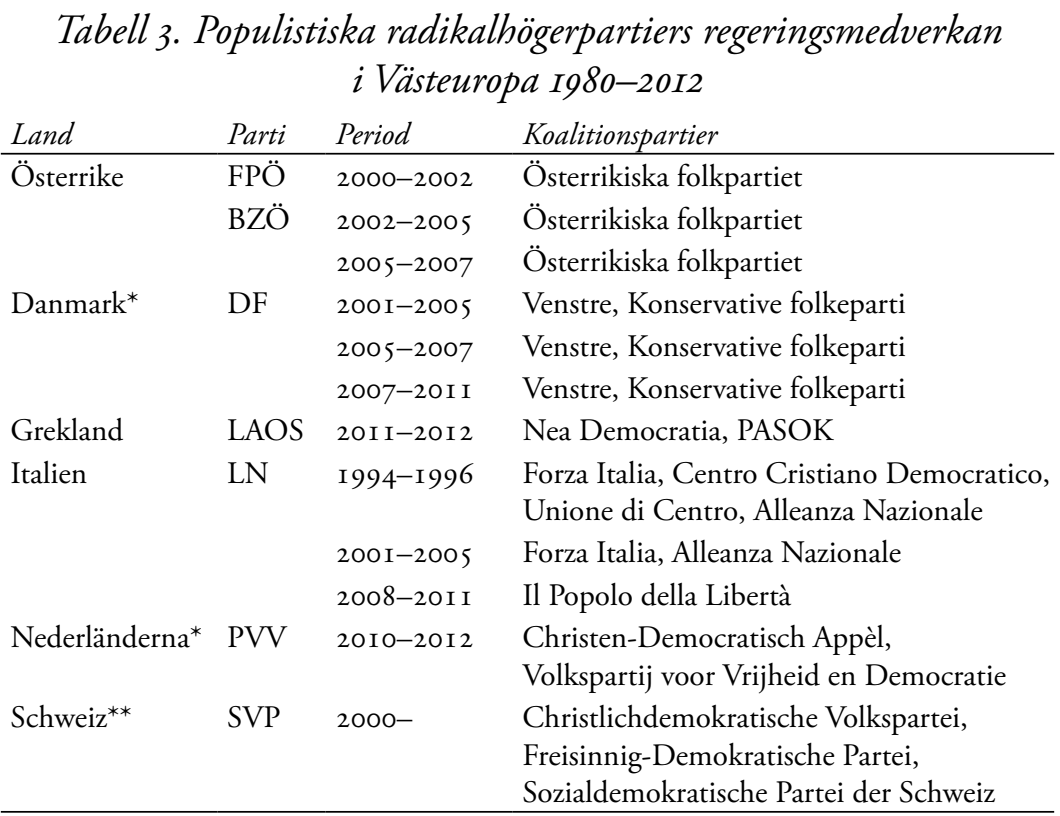

* Minoritetsregeringar där det populistiska radikalhögerpartiet fungerat som officiellt stödparti.

** Schweiziska regeringar, förbundsrådet, är en form av permanenta koalitionsregeringar där ministerposterna fördelas enligt överenskommelse mellan de största partierna och med hänsyn till representation för landets regioner och språk. SVP stod utanför regeringen under några månader 2008 på grund av interna stridigheter och splittring. 
inte alltid vara relaterad till vare sig populistiska radikalhögerpartiers valframgångar eller regeringsmedverkan.

I en del fall kan vi se att denna förskjutning i migrationsfrågor följer de förutsägelser som följer av Christopher Wleziens (1995) berömda "termostatiska modell": ökad uppmärksamhet på frågor om invandring leder till valframgångar för populistiska radikalhögerpartier, och en ökad policyutveckling på området. Den här utvecklingen har vi till exempel kunnat se i Danmark, där invandringsfrågor först fick väsentligt utökat utrymme mellan 1990 och 200I, vilket ledde till att Dansk folkeparti fick sitt stora genombrott och sina första valframgångar, men där uppmärksamheten på frågan sedan sjönk, efter en mandatperiod där Dansk folkeparti stött en minoritetsregering och invandringslagarna skärptes (Meret 20II, s. 248).

Frågan om populistiska radikalhögerpartiers påverkan på den allmänna opinionen är mycket omdebatterad, och forskningen på området har endast bidragit med att öka förvirringen. Vissa studier slår fast att dessa partier på ett signifikant sätt påverkar befolkningens förhållningssätt till invandring och integration (t.ex. Sprague-Jones 20II; Semyonov m.fl. 2006), andra studier visar på mer begränsade effekter från vad man kallar "kulturrasistiska partier" (Wilkes m.fl. 2007) eller "entreprenörsmässiga radikala högerpartier" (Williams 2006), och en tredje grupp studier kan inte hitta någon signifikant effekt alls (t.ex. Dunn \& Singh 20II). Förvirringen kan delvis förklaras med att studierna fokuserar på olika aspekter av invandringsfrågan, liksom med att de studerar olika slags data och olika tidsperioder, men den indikerar i alla fall inte att omvälvande förändringar i den allmänna opinionen följer på de framgångar som populistiska radikalhögerpartier har vid allmänna val.

Populistiska radikalhögerpartier är ofta skeptiska till EU, och många politiska kommentatorer har länkat samman den allmänt ökade EUskepticismen med dessa partiers framgångar (t.ex. Krouwel \& Abts 2007). Det saknas dock, såvitt jag kan se, någon som helst forskning som empiriskt har kunnat belägga denna korrelation, och än mindre fastställa existensen av en kausal förbindelse. Däremot finns det gott om empirisk forskning som pekar åt ett annat håll. Om vi studerar Eurobarometerns redovisning av stödet för den europeiska integrationen och hur det varie- 
rar mellan olika tidpunkter och olika länder, kan vi se att det fluktuerar på ett ryckigt och oregelbundet sätt, tillsynes oberoende av valresultaten. Därtill kommer tendensen till ett minskande stöd för den europeiska integrationen som, åtminstone sedan Maastrichtfördraget, är lika tydligt i hela Europa (Eichenberg \& Dalton 2007).

Det är svårt att hitta jämförande data mellan olika länder när det gäller attityder relaterade till brott, och de har ofta bara begränsade uppgifter. Eurobarometern mätte känslan av otrygghet relaterat till brott vid tre olika tillfällen (1996, 2000 och 2002). Resultatet tyder på en möjlig svag korrelation med valframgångar för populistiska radikalhögerpartier, men inte med regeringsdeltagande. Andra data är ännu mer svårtydda, och visar i allmänhet antingen ganska stabila positioner eller ganska oförutsägbara förändringar som inte kan relateras till valresultat eller regeringsmedverkan (t.ex. Van Dijk m.fl. 2006; Kesteren 2009).

Slutligen, ett av huvudbudskapen i de populistiska radikalhögerpartiernas propaganda är att korrupta eliter har kidnappat det politiska systemet och tystat folkets röst genom uppgörelser i slutna rum och genom att genomdriva en "tystnadskonspiration". Vid första anblicken verkar det som att de har lyckats övertyga en växande del av befolkningen. Västeuropa har sett ett avtagande förtroende för politiska institutioner och för den nationella demokratin. Men mycket av det växande missnöjet inträffade redan före att de här partierna fick luft under vingarna och var förmodligen snarare en orsak till deras framgångar än en effekt av den. Vidare kan man vid en snabb blick på Eurobarometern se att allmänhetens förtroende för den nationella demokratin varierar mycket och saknar koppling till populistiska radikalhögerpartiers valframgångar eller regeringsdeltagande.

Sammanfattningsvis, medan populistiska radikalhögerpartier kan ha påverkat positionen och betydelsen av vissa frågor för några delar av befolkningen, verkar de sällan ha ändrat deras mer långsiktiga attityder. Som jag hävdat i andra sammanhang (Mudde 2oro) behövde de egentligen inte heller göra det, eftersom många européer redan uppvisade attityder som var i enlighet med de grundläggande delarna av den populistiska radikala högerideologin (om än i en mer moderat form). 


\section{Partierna}

När man tittar på partiernas nivå, kan "högervridningstesens" argument delas upp i två delar: mainstreampartierna har blivit mer "nativistiska", auktoritära och populistiska; och detta beror på valkonkurrensen från de populistiska radikalhögerpartierna. De flesta författare hävdar att populistiska radikalhögerpartier bara har influerat mainstreampartier inom högern. Ett bra exempel på detta är Jean-Yves Camus (20II, s. 83; se även Schain 2006), som argumenterar för att "Nationella frontens ideer ... har haft ett inflytande på högerns politiska agenda när det gäller frågor som invandring, brottslighet, mångkulturalism och definitionen av nationell identitet”. Några politiserande inlägg går ännu längre, och hävdar att den populistiska radikalhögerns inflytande kan ses över hela det politiska spektrumet, åtminstone från mainstreamhögern till mainstreamvänstern.

Vid en första anblick verkar det som att det senare argumentet är det som är mest korrekt, åtminstone vad gäller invandringspolitiken (t.ex. Spanje 20IO). En jämförelse mellan valmanifest mellan 1975 och 2005 visade att både mainstreamhögern och mainstreamvänstern hade lagt större vikt vid invandring och intagit en striktare position; effekten var mest uttalad under perioden 1995-2005 (Alonso \& Claro da Fonseca 20I2). Emellertid, medan en ökad betoning av invandringsfrågan är relaterad till närvaron av ett relevant populistiskt radikalhögerparti, är förändringen till en striktare invandringspolitik inte det. Eller mer exakt, inte för partier inom mainstreamhögern! Med andra ord, i länder utan ett framgångsrikt populistiskt radikalhögerparti kommer mainstreamvänstern att hålla sig borta från invandringsfrågan, men mainstreamhögern kommer att inta en striktare invandringspolitik i vilket fall, eftersom de ser det som en lovande valfråga (se också Mudde 2007; Bale 2008). Intressant nog verkar partier inom mainstreamhögern också vara oberörda av deltagande i koalitioner med populistiska radikalhögerpartier (Spanje 20IO), vilket betyder att deras strikta invandringspolitik föregår dessa koalitioner och faktiskt gör dem möjliga (se de Lange 20I2).

Det är viktigt att komma ihåg att det som fortfarande betraktas som "invandringsfrågan" faktiskt är ett mångfacetterat komplex av relaterade men separata frågor, vilka inkluderar både invandring (inklusive politisk 
asyl) och integration. Den mesta forskningen blandar samman dem, och antar att partier har liknande öppen eller restriktiv syn på båda frågorna, men detta är inte sant. Utifrån en analys av de europeiska partisammanslutningarnas plattformar, drar Fraser Duncan och Steven Van Hecke slutsatsen (2008, s. 432):

Medan kristdemokratiska och konservativa partier inte skiljer sig på ett avgörande sätt från sina socialistiska motsvarigheter när det gäller kontrollfrågor, är liberala partier mindre restriktiva. När det gäller integration, är både kristdemokrater, konservativa och liberaler mindre mångkulturella än socialistiska och gröna partier.

Med andra ord, i de fall där den populistiska radikalhögern har kunnat influera andra partier vad gäller den bredare invandringsfrågan, har det varit tvärs över det politiska spektrumet gällande invandringskontroll (huvudsakligen politisk asyl), men ändå bara på den högra sidan av spektrumet när det gäller integration.

Om andra frågor finns mindre forskning tillgänglig. Det ökade talet om lag och ordning anses ofta bero på konkurrens med de populistiska radikalhögerpartierna. Men auktoritära lösningar är en brett omfattad ideologisk företeelse, och förmodligen snarare resultatet av den konservativa våg som inleddes på 1980-talet än av de populistiska radikalhögerpartiernas uppgång på 1990-talet (se Ignazi 1992). På senare tid har det tidiga 2000-talets terroristattacker och det därpå följande "kriget mot terrorismen" varit den viktigaste faktorn bakom det fokus på säkerhetsfrågor som nu omfattar de flesta politiska områden (t.ex. Haubrich 2003).

Slutligen, i enlighet med min egen argumentation när det gäller uppkomsten av en populistisk Zeitgeist (Mudde 2004), talar Gianpietro Mazzoleni (2008, s. 57) om "den 'populistiska förgiftningen' av den politiska mainstreamdiskursen". Argumentet är inte att alla politiska partier i Västeuropa blivit i allt väsentligt populistiska partier, utan att de flesta partier använder populistiska teman i sin politiska diskurs. Användningen av denna "mjuka populism" är inte begränsad till mainstreampartier i de partisystem som har starka populistiska radikalhögerpartier. För det första fungerar i den här frågan några andra viktiga partier i Europa som funktionella ekvivalenter - de flesta uttalat nyliberala 
populistpartier som Forza Italia och Fremskrittspartiet. För det andra har mainstreampartier också i länder utan något signifikant populistparti börjat använda populistisk retorik. Ett ofta nämnt exempel är New Labour i Storbritannien, särskilt under Tony Blair (t.ex. Mazzoleni 2008).

\section{Politiken}

Även om jämförande forskning inte är tillgänglig för alla politikområden, verkar det stå klart att europeisk politik i allmänhet sedan 1980talet lagts om i mer auktoritär riktning, särskilt i frågor som handlar om invandring och integration, liksom brottslighet och "nationell säkerhet". Politiken vreds ännu mer åt höger efter II september-attackerna 200I, vilket lett till att en rad olika politikområden influerats av ett fokus på säkerhet - inte minst invandringsfrågor. Medan några författare har visat att regeringar med populistiska radikalhögerpartier successivt har drivit igenom den politik dessa partier föredrar i frågor som anknyter till invandring, integration och lag och ordning, om än med större variation än vad som vanligtvis brukar erkännas (t.ex. Akkerman \& de Lange 20I2), har andra således visat upp en liknande utveckling i länder utan sådana partier i regeringen eller ibland ens i parlamentet, vilket indikerar en konvergens mot striktare invandringspolitik i hela EU-området (t.ex. Givens \& Luedtke 2004; Schain 2009). Även om det är sant att länder med stora populistiska radikalhögerpartier har lanserat mer "populistisk radikal höger"-lagstiftning, är dessa policyeffekter i bästa fall indirekta - det vill säga, de är en återspegling av förändringar i de politiska preferenserna hos mainstreampartierna på grund av hur de uppfattar konkurrensen från den populistiska radikalhögern (se ovan).

Den mesta forskningen om populistiska radikalhögerpartiers regeringsmedverkan fokuserar enbart på invandrings- och integrationspolitik, vilket följer Michael Minkenbergs (200I, s. I) tidiga slutsats: "När den radikala högern finns i regeringsställning, sker 'högervridningen' i första hand i kulturpolitiken." Andrej Zaslove, till exempel, hävdar att "Frihetspartiet [FPÖ] och Lega Nord har varit avgörande för att driva igenom mer restriktiv invandringspolitik, som begränsar flödet av invandrare och möjligheterna för arbetskraft som inte kommer från EU-länder att bo, arbeta och etablera sig i antingen Österrike eller Italien” (Zaslove 2004, 
s. 99). Populistiska radikalhögerpartier som stödjer minoritetsregeringar verkar också ha haft sina främsta framgångar när de påverkar invandringslagstiftningen (t.ex. Meret 20II).

Många författare har varnat för alltför starka slutsatser utifrån detta, och menat att mot dessa framgångar på invandringspolitikens område står också många bakslag. De har enbart noterat ett begränsat inflytande för populistiska radikalhögerpartier inom deras respektive regeringar (t.ex. Albertazzi 2008; Heinisch 2008; Luther 20II; Tarchi 2008). Angående den politik som förts av Berlusconis regeringar i Italien, till exempel, konstaterar Marco Tarchi (2008, s. 97): "några av de frågor som låg de populistiska väljarnas hjärta nära hanterades, men på ett mycket mer avvägt sätt än vad som föreslogs av regeringspartiernas, särskilt Lega Nords, partiprogram.” Kort sagt, resultatet av den populistiska högerns medverkan i olika regeringar ser inte särskilt imponerande ut, ens när det gäller nyckelfrågan invandring (Akkerman 20I2).

\section{Styrelseformerna}

Om vi betraktar resultatet av den tidigare analysen kan det inte förvåna att de populistiska radikalhögerpartierna inte har påverkat det politiska systemet i Västeuropa. Inget av de europeiska länderna har blivit auktoritärt - inte ens de som har sådana partier i regeringen. Detta kan verka självklart i dag, men mycket av det akademiska och offentliga intresset för den här partifamiljen har utlösts av förmodanden om att den populistiska radikalhögern är ett hot mot det existerande politiska systemet på grund av dess föregivet antidemokratiska karaktär.

Närmare besett är det inte förvånande att de populistiska radikalhögerpartierna inte förändrat den demokratiska karaktären hos systemet med tanke på att de stödjer både folksuveränitetsprincipen och majoritetsstyre. Deras förhållande till den liberala demokratin är dock mindre entusiastiskt, de är essentiellt monister, mycket skeptiska till minoriteters rättigheter och kompromisspolitik (Mudde 2007). Dessutom har de i flera fall försökt underminera oberoendet hos balanserande politiska institutioner - framför allt domstolarna och medierna - liksom de försökt begränsa minoriteters rättigheter. Emellertid har de juridiska utmaningarna i stort sett varit framgångslösa och angreppen i huvudsak retoriska. 
Den tveklöst mest omfattande utmaningen mot den liberala demokratin i Västeuropa har kommit från Berlusconis olika regeringar i Italien, även om det huvudsakligen varit på initiativ av nyliberala populistiska Forza Italia snarare än det populistiska radikalhögerpartiet Lega Nord. Med uppbackning av sitt privata medieimperium har Berlusconi engagerat sig i decennier av populistisk retorik på bekostnad av de andra partierna, domstolarna och vem som nu motsatt sig honom. Men när hans regering föreslog kontroversiella reformer av det politiska systemet, som särskilt skulle ge premiärministern mycket mer makt, antingen misslyckades det eller så utmanade det knappast de institutioner (och praktiker) som utgjorde systemet i stort (t.ex. Ruzza \& Fella 2009).

I korthet, medan de populistiska radikalhögerpartierna aldrig har utmanat själva essensen av det demokratiska systemet, kan samma sak inte sägas om den liberala demokratin. Det faktum att inget land förändrats till en "illiberal demokrati" (Zakaria 1997), inte ens när populistiska radikalhögerpartier suttit i regeringsställning, beror på uthålligheten hos koalitionspartierna, det civila samhället och domstolarna. Det är här som det sena 1900-talets europeiska demokratier starkast avviker från den tidiga I900-talets.

\section{En högervridning ... men vilken höger?}

Minkenbergs effektiva sammanfattning av hur populistiska radikalhögerpartier väsentligen har influerat europeiska demokratier baseras på ett mycket begränsat antal fall och gjordes för över tio år sedan, men är fortfarande giltig: "Regeringen 'av folket, genom folket, för folket' är inte ifrågasatt, men däremot begreppet 'folk'” (Minkenberg 200I, s. 2I). I den utsträckning dessa partier har påverkat europeiska demokratier, har det handlat om att omdefiniera folket; eller, mer korrekt, omdefiniera folket på det sätt som det alltid implicit definierats i det för-mångkulturella samhället - nämligen som etniskt homogent. Inflytandet har mestadels varit indirekt och i linje med det demokratiska framsteget på så vis att populistiska radikalhögerpartier gjort politik av antiinvandringsuppfattningar som huvudsakligen redan existerat, vilket uppmuntrat mainstreampartier (om uppmuntran nu var nödvändig) att 
ta upp dessa frågor och ställningstaganden, om än på ett mer balanserat sätt, och på motsvarande sätt ändra politiken (jfr Schain 2006).

Emellertid, trots att några populistiska radikalhögerpartier kan ses som katalysatorer i den här processen, är deras handlande varken en nödvändig eller en tillräcklig orsak. Deras framgång blev möjlig därför att det redan tidigare fanns en bördig jordmån för folkligt missnöje runt invandring, brott och partipolitik runt om i Västeuropa (t.ex. Betz I994; Mudde 20IO). Detta förklarar varför länder utan framgångsrika sådana partier gick genom ungefär samma process. Till exempel visar undersökningar en betydande ökning av missnöje riktat mot invandringen i alla europeiska länder mellan I988 och 2000 (Semyonov m.fl. 2006, s. 426), men ökningen var störst under periodens tidigare del (1988-1994), vilket är strax innan den mest markerade förändringen mot en position av ökat invandringsmotstånd inträffade bland kontinentens politiska mainstreampartier (Alonso \& Claro da Fonseca 20I2).

Med andra ord har mainstreampartier större ansvar än populistiska radikalhögerpartier för det ökade invandringsmotståndet under senare tid (Bale 2008). Medan alla rört sig i riktning mot en mer begränsad invandring, har en del valt att särskilt använda den frågan för att vinna regeringsmakten genom att närma sig antingen de populistiska radikalhögerpartierna (t.ex. Österrike, Danmark, Nederländerna) eller deras väljare (t.ex. Frankrike). I de flesta av dessa fall har mainstreamhögern inte bara antagit en radikalare position i invandringsfrågan, utan de har även implementerat striktare invandringspolitik än i andra länder. Slutligen kan vi konstatera att medan trycket från den populistiska radikala högerns väljare har ett inflytande på partierna inom mainstreamvänstern, är detta åtminstone förmedlat via mainstreamhögerns reaktioner (Bale m.fl. 20Io). Kort sagt, enbart närvaron av starka populistiska radikalhögerpartier leder varken automatiskt till en mer negativ inställning till invandring i ett land, eller innebär att den liberala kosmopolitismen försvinner från det politiska systemet: politiken betyder något - särskilt den politik som förs av mainstreamhögerns partier (Bale 2008).

Den europeiska integrationen var, liksom invandringen, länge en tabubelagd fråga i europeisk politik, ofta medvetet exkluderad från den politiska agendan av de politiska eliterna. Att Europa skulle integreras 
var emellertid en fråga som, till skillnad från invandringen, länge kunde räkna med en eftergiven konsensus bland befolkningen i stort. Sedan det tidiga 1990-talet har det folkliga stödet för den europeiska integrationen emellertid minskat, i några länder starkt, även om det direkta avvisandet av idén ökat i mer begränsad mån. Mainstreampartier har också blivit försiktigare när det gäller den europeiska integrationen, och uttrycker alltmer en "mjuk euroskepticism" inom den nationella politiken (t.ex. Szczerbiak \& Taggart 2008), även om den tillåtande konsensusen bland eliterna verkar vara i stort sett intakt.

Det är knappast troligt att populistiska radikalhögerpartier spelat någon viktigare roll $\mathrm{i}$ senare tiders sviktande stöd för den europeiska integrationen. För det första är mycket av kritiken relaterad till en ny utveckling inom EU, som inleddes med Maastrichtfördraget 1992, vilken delvis utmanar de visioner om europeisk integration som mainstreampartierna och deras anhängare föredrar. Med andra ord, samtidigt som EU blivit tydligare definierat, har fler människor och partier sett vissa saker som de tycker är fel. För det andra har de flesta uttalat europaskeptiska partierna i dag utvecklat sin position oberoende av, och ofta långt innan, den populistiska radikala högern blivit relevant (Szczerbiak \& Taggart 2008). Och för det tredje kommer det starka motståndet mot delar av den europeiska integrationen åtminstone lika mycket från andra politiska aktörer - framför allt radikala vänsterpartier och fackföreningar (som i fallet med de nederländska och franska omröstningarna om den "europeiska konstitutionen").

Populistiska radikalhögerpartier har inte heller betytt så mycket för den auktoritära vändningen i Västeuropa. Liksom när det gäller invandring, har det alltid funnits en signifikant klyfta mellan de mer progressiva eliterna och de mer konservativa massorna när det gäller frågor som har att göra med brottslighet. Den politiska förändringen började i de flesta länder på 1980-talet, som en konsekvens av det nykonservativa inflytandet inom mainstreamhögern (och ibland inom vänstern), långt innan den populistiska radikalhögern började få ett betydande stöd bland väljarna. Och medan populistiska radikalhögerpartier har varit starka anhängare av strikt antiterrorlagstiftning, har det inom den politiska mittfåran funnits ett brett stöd för hur säkerhetsfrågor satts i fokus efter 
II september 200I, och den utvecklingen behövde varken dessa partiers initiativ eller stöd.

Med en uttalad anti-etablissemangs-diskurs ivrar många populistiska radikalhögerpartier för att introducera folkomröstningar som ett sätt att "demokratisera" de politiska systemen och bryta "det korrupta politiska etablissemangets" makt (Mudde 2007). De verkar emellertid inte ha varit särskilt framgångsrika, eller haft mycket att säga till om, när det gäller den frågan. Medan antalet nationella folkomröstningar i Västeuropa utan tvekan har ökat, är de flesta av dessa relaterade till den europeiska integrationen och antingen resultat av konstitutionella krav eller tryck från andra politiska aktörer.

Kort sagt, medan "högervridningstesen" verkar ha rätt när den beskriver en rörelse mot mer högerinriktade positioner gällande sociokulturella frågor hos både massor och eliter, har den fel ifråga om den huvudsakliga orsaken till denna process. Snarare än den populistiska radikalhögern, har det varit mainstreamhögern som fört den västeuropeiska politiken högerut, delvis som ett svar på hur medierna och allmänheten reagerat på den senaste tidens utveckling (såsom mångkulturella samhällen, Maastrichtfördraget och II september-attackerna). I många fall har mainstreamvänstern visat sig antingen inkompetent när det gäller att bromsa utvecklingen (till exempel vad gäller integration) eller anmärkningsvärt samarbetsvillig när det handlar om att stödja den (till exempel gällande invandringskontroll och fokus på säkerhetsfrågor).

\section{Att förklara de populistiska radikalhögerpartiernas begränsade inverkan}

En av de främsta orsakerna till den begränsade inverkan av de populistiska radikalhögerpartierna är att de snarare är "renhetsivrare" än "profeter" (Lucardie 2000). De driver på för politiska förändringar inom ramen för frågor som redan existerar, inte för nya frågor (som de gröna gjorde med miljön). Ett bra exempel är den föregivet nya frågan invandringskontroll. Manöverutrymmet på just detta fält var redan väsentligt begränsat innan den tredje vågen av radikal höger ens inleddes. De flesta västeuropeiska länder hade redan i stort sett förbjudit ekonomisk 
invandring 1973-1974, som ett svar på oljekrisen, långt innan invandringskontrollen politiserades (på sent $1980-t a l$ ). Denna politik hade i stort sett betraktats som en rent teknisk åtgärd och accepterades i stort sett över hela det politiska spektrumet (t.ex. Rydgren 2008).

Det mest uppenbara skälet är emellertid det relativt begränsade stöd som dessa partier uppnår vid parlamentsval. Med ett genomsnittligt stöd om mindre än ıo procent av väljarna är få populistiska radikalhögerpartier bland de viktigaste partierna i sina nationella politiska system. Dessutom tar sig än färre in i regeringarna, oavsett om det är majoritetseller minoritetsregeringar, och de flesta undviks av övriga partier i parlamenten. Det direkta politiska inflytandet är följaktligen ganska sällsynt. Och även när de tar sig till makten, är de hundar som skäller högt, men nästan aldrig biter.

Det finns åtminstone fem orsaker till att populistiska radikalhögerpartier är regeringsodugliga. För det första fokuserar de bara på ett fåtal frågor, vilket signifikant reducerar omfånget för deras inflytande, även om de är framgångsrika. Viktigast är att socioekonomiska frågor för dem bara har sekundärt värde, och hamnar i bakgrunden till förmån för sociokulturella frågor i förhandlingar med deras koalitionspartners (de Lange 2012). För det andra är politiska partier bara en av de många olika slags aktörer som skapar politik: byråkratier och frivilligorganisationer begränsar väsentligt manöverutrymmet för partier (se Duncan 20Io). Detta är ännu mer fallet för nya regeringspartier, särskilt de från den populistiska radikalhögern, som har få anhängare i de dominerande politiska nätverken. För det tredje är populistiska radikalhögerpartier alltid den mindre partnern i koalitioner, mycket mindre erfarna än både deras koalitionspartner och andra aktörer inom de politiska nätverken. De har därmed ofta bara nominell kontroll över sina politikområden, även när de officiellt kontrollerar ministerposter (t.ex. Heinisch 2008; Luther 20II). För det fjärde är koalitionsregeringar resultat av en politisk konvergens mellan mainstreampartier och den populistiska radikalhögern, som föregår regeringssamarbetet (se de Lange 20I2). Därför återspeglar många koalitionsregeringars politik även när det gäller den populistiska radikala högerns frågor som invandring minst lika mycket programmen hos mainstreamhögerns partier (t.ex. Duncan 20I0; Tarchi 
2008). För det femte, och sista, föredrar populistiska radikalhögerpartier att hålla "en fot innanför och en fot utanför" regeringen (Albertazzi m.fl. 20II, s. 479). Därför föredrar de att upprätthålla bilden av sig själva som oppositionella, genom att använda radikal retorik och genom att driva på för överdrivet radikal politik, snarare än att riskera att betraktas som "normala" regeringspartier och del av "den korrupta eliten" (t.ex. Luther 20II).

\section{Allt lugnt på västfronten?}

Detta betyder inte att populistiska radikalhögerpartier alltid kommer att förbli ett relativt obetydligt obehag i de västeuropeiska demokratierna, även om det är viktigt att komma ihåg att under de senaste tre decennierna har de viktigaste hoten mot den liberala demokratin kommit från den politiska mittfåran snarare än från de politiska extremerna - det vill säga, Silvio Berlusconi i Italien, bröderna Kaczynski i Polen och för närvarande Viktor Orbán i Ungern, liksom från antiterrorlagstiftningen efter II september-attackerna. Bortsett från detta är det fortfarande viktigt att fortsätta vara vaksam mot de populistiska radikalhögerpartierna. Det finns åtminstone tre orsaker till att de skulle kunna bli mer inflytelserika i en (nära) framtid.

För det första har vi under de senaste decennierna, delvis på grund av de populistiska radikalhögerpartiernas framgångar, men främst på grund av massmediernas omvandling, sett en tabloidisering, ett ökat inflytande för sensations- och underhålningsjournalistiken inom den politiska diskursen. Kvällstidningar och sådana här partier delar många attityder och frågor, vilka kommit att dominera den politiska diskursen i Europa under de senaste decennierna (t.ex. Mazzoleni 2008). Samtidigt som detta inte nödvändigtvis kan överföras till förändrade allmänna attityder och politiska förändringar, skapar det åtminstone en mer gynnsam "diskursiv möjlighetsstruktur" (Koopmans \& Statham I999, s. 228) för populistiska radikalhögerpartier och deras politik.

För det andra kommer de här partierna att ha än större framgångar i allmänna val. Det finns inte bara fler framgångsrika partier i dag än för trettio år sedan, många är också etablerade i sina nationella politiska 
system. Och samtidigt som den ekonomiska krisen bromsat deras framgångar i valen, genom att återföra debatten till socioekonomiska snarare än sociokulturella frågor, finns det goda skäl att tro att de populistiska radikalhögerpartierna kan växa på nytt på andra sidan krisen. Framför allt har EU:s svar på den ekonomiska krisen skapat en oro kring hur kontinenten ska kunna hålla samman och ytterligare exponerat de fundamentala skillnaderna i åsikter mellan eliterna och massorna om hur angeläget det är att fortsatt arbeta för europeisk och global integration. I många länder har populistiska radikalhögerpartier redan svarat på detta genom att kräva att integrationen minskas i olika mån, vilket är något som kan bli en populärare åsikt när folk åter känner sig säkrare vad gäller ekonomin.

För det tredje har en del av de framgångsrika populistiska radikalhögerpartierna vuxit upp. De har lärt sig av misstag under sina första kontakter med makten och har ofta fătt mer erfarenhet av politik på lokal och regional nivå. Många betraktare har generaliserat utifrån bara två fall - österrikiska Frihetspartiet (FPÖ) och nederländska Lijst Pim Fortuyn (LPF) - vilka båda imploderat när de fått ta regeringsansvar. Detta är dock på intet sätt en allmän regel. Italienska Lega Nord överlevde tre regeringar i stort sett oskadat medan Dansk folkeparti och (förmodligen) nederländska Frihetspartiet (PVV) verkar ha klarat sitt stöd för minoritetsregeringar utan bakslag (t.ex. Heinisch 2003; Mény \& Surel 2002). Liksom socialdemokratiska partier före andra världskriget, och gröna partier under 1990-talet, kan dessa partier klara omvandlingen från framgångsrika oppositionspartier till fungerande regeringspartier (se Luther 20II; McDonnell \& Newell 20II). Dessutom, när mainstreampartier i ökande grad konvergerar med den populistiska radikalhögern inom sociokulturell politik, och de senare fortsätter att kompromissa när det gäller socioekonomiska frågor, kan populistiska radikalhögerpartier mycket väl fortsätta vara mer attraktiva (det vill säga "billigare") koalitionspartier för mainstreamhögern.

Men även om det osannolika skulle inträffa och populistiska radikalhögerpartier får ett avgörande inflytande på västeuropeisk politik, är det föga troligt att detta kommer att leda till en fundamental förändring av det politiska systemet. När allt kommer omkring är den 
populistiska radikala högern inte en normal patologi inom den europeiska demokratin, utan relation till dess grundläggande värderingar, utan snarare en patologisk normalitet, som strävar efter att radikalisera mainstreamvärderingar.

\section{Översättning: Fredrik Hertzberg och Mats Deland}

\section{Referenser}

Akkerman, Tjitske 2012. "Comparing Radical Right Parties in Government. Immigration and Integration Policies in Nine Countries (1996-2010)", West European Politics, 35, 3, s. 5II-529.

DoI: http://dx.doi.org/IO.IO80/oI402382.20I2.665738

Akkerman, Tjitske \& de Lange, Sarah L. 20I2. "Radical Right Parties in Office. Incumbency Records and the Electoral Cost of Governing", Government and Opposition, 47,4 , s. $574-596$.

DoI: http://dx.doi.org/IO.IIII/j.I477-7053.2012.01375.x

Albertazzi, Daniele 2008. "Switzerland: Yet Another Populist Paradise", i Albertazzi, Daniele \& McDonnell, Duncan (red.) Twenty-first Century Populism. The Spectre of Western European Democracy. Basingstoke: Palgrave Macmillan.

Albertazzi, Daniele, McDonnell, Duncan \& Newell, James L. 20II. "Di lotta e di governo. The Lega Nord and Rifondazione Comunista in Office", Party Politics, I7, 4, s. 47I-487.

DoI: http://dx.doi.org/IO.II77/13540688II400523

Alonso, Sonia \& Claro da Fonseca, Sara 20I2. "Immigration, Left and Right", Party Politics, I8, 6, s. 865-884. DoI: http://dx.doi.org/IO.II77/1354068810393265

Bale, Tim 2008. "Politics Matters. A Conclusion", Journal of European Public Policy, I5, 3, s. 453-464. DOI: http://dx.doi.org/Io.IO80/1350I76070I84772I

Bale, Tim m.fl. 2oro. "If You Can't Beat Them, Join Them? Explaining Social Democratic Responses to the Challenge from the Populist Radical Right in Western Europe", Political Studies, 58, 3, s. 410-426.

DoI: http://dx.doi.org/I0.IIII/j.I467-9248.2009.00783.x

Betz, Hans-Georg 1994. Radical Right-wing Populism in Western Europe. London: Macmillan.

Beyme, Klaus von 1988. "Right-wing Extremism in Post-war Europe", West European Politics, II, 2, s. I-I8. DOI: http://dx.doi.org/Io.IO80/oI402388808424678

Camus, Jean-Yves 20II. "The Extreme Right in France. Redrawing the Map to be Expected", i Langenbacher, Nora \& Schellenberg, Britta (red.) Is Europe on the "Right" 
Path? Right-wing Extremism and Right-wing Populism in Europe. Berlin: Friedrich Ebert Stiftung.

de Lange, Sarah L. 20I2. "New Alliances. Why Mainstream Parties Govern with Radical Right-wing Populist Parties", Political Studies, 60, 4, s. 899-918. DOI: http://dx.doi.org/IO.IIII/j.I467-9248.20I2.00947.x

Duncan, Fraser 20I0. "Immigration and Integration Policy and the Austrian Radical Right in Office: the FPÖ/BZÖ, 2000-2006", Contemporary Politics, I6, 4, s. 337-354. DoI: http://dx.doi.org/IO.IO80/13569775.2010.523935

Duncan, Fraser \& Van Hecke, Steven 2008. "Immigration and the Transnational European Centre-right. A Common Programmatic Response?", Journal of European Public Policy, I5, 3, s. 432-452. DoI: http://dx.doi.org/I0.I080/1350I76070I847705

Dunn, Kris P. \& Singh, Shane P. 20II. "The Surprising Non-impact of Radical Rightwing Populist Party Representation on Public Tolerance of Minorities", Journal of Elections, Public Opinion and Parties, 21, 3, s. 313-331. DoI: http://dx.doi.org/Io.Io80/I7457289.2011.588333

Eichenberg, Richard C. \& Dalton, Russell J. 2007. "Post-Maastricht Blues. The Transformation of Citizen Support for European Integration, 1973-2004", Acta Politica, 42, 2-3, s. I28-I52.

DoI: http://dx.doi.org/I0.I057/palgrave.ap.5500I82

Givens, Terri \& Luedtke, Adam 2004. "The Politics of European Union Immigration Policy. Institutions, Salience and Harmonization", Policy Studies Journal, 32, I, s. $145-165$. Dor: http://dx.doi.org/IO.IIII/j.0190-292X.2004.00057.x

Haubrich, Dirk 2003. "September II, Anti-terror Laws and Civil Liberties: Britain, France and Germany Compared", Government and Opposition, 38, I, s. 3-28. DOI: http://dx.doi.org/IO.IIII/I477-7053.00002

Heinisch, Reinhard 2003. "Success in Opposition - Failure in Government: Explaining the Performance of Right-wing Populist Parties in Public Office", West European Politics, 26, 3, s. 9I-I30. DOI: http://dx.doi.org/Io.I080/0I402380312331280608

Heinisch, Reinhard 2008. "Austria: The Structure and Agency of Austrian Populism", i Albertazzi, Daniele \& McDonnell, Duncan (red.) Twenty-first Century Populism. The Spectre of Western European Democracy. Basingstoke: Palgrave Macmillan.

Ignazi, Piero 1992. "The Silent Counter-revolution. Hypotheses on the Emergence of Extreme Right-wing Parties in Europe”, European Journal of Political Research, 22, I, s. 3-34. DoI: http://dx.doi.org/IO.IIII/j.I475-6765.I992.tboo303.x

Inglehart, Ronald 1977. The Silent Revolution. Changing Values and Political Styles among Western Publics. Princeton: Princeton University Press.

Kesteren, John van 2009. "Public Attitudes and Sentencing Policies across the World", European Journal of Criminal Policy and Research, I5, I-2, s. 25-46. DoI: http://dx.doi.org/10.1007/sio610-009-9098-7 
Koopmans, Ruud \& Statham, Paul 1999. "Ethnic and Civic Conceptions of Nationhood and the Differential Support of the Extreme Right in Germany and Italy", i Giugni, Marco, McAdam, Doug \& Tilly, Charles (red.) How Social Movements Matter. Minneapolis: University of Minnesota Press.

Krouwel, André \& Abts, Koen 2007. "Varieties of Euroscepticism and Populist Mobilization. Transforming Attitudes from Mild Euroscepticism to Harsh Eurocynicism", Acta Politica, 42, 2-3, s. 252-270.

DoI: http://dx.doi.org/I0.I057/palgrave.ap.5500I87

Lipset, Seymour M. \& Rokkan, Stein 1967. Party Systems and Voter Alignments. Crossnational Perspectives. New York: Free Press.

Lucardie, Paul 2000. "Prophets, Purifiers and Prolocutors. Towards a Theory on the Emergence of New Parties", Party Politics, 6, 2, s. 175-185. DOI: http://dx.doi.org/I0.II77/I354068800006002003

Luther, Kurt Richard 20II. "Of Goals and Own Goals. A Case Study of Right-wing Populist Party Strategy for and during Incumbency", Party Politics, 17, 4, s. 453-470. DOI: http://dx.doi.org/IO.II77/I354068811400522

Mair, Peter 1997. Party System Change. Approaches and Interpretations. Oxford: Clarendon Press.

Mazzoleni, Gianpietro 2008. "Populism and the Media", i Albertazzi, Daniele \& McDonnell, Duncan (red.) Twenty-first Century Populism. The Spectre of Western European Democracy. Basingstoke: Palgrave Macmillan.

McDonnell, Duncan \& Newell, James L. 20II. "Outsider Parties in Government in Western Europe", Party Politics, I7, 4, s. 443-452. DOI: http://dx.doi.org/Io.1177/1354068811400517

Mény, Yves \& Surel, Yves 2002. ”The Constitutive Ambiguity of Populism”, i Mény, Yves \& Surel, Yves (red.) Democracies and the Populist Challenge. Basingstoke: Palgrave Macmillan.

Meret, Susi 20Ir. "From the Margins to the Mainstream? The Development of the Radical Right in Denmark", i Langenbacher, Nora \& Schellenberg, Britta (red.) Is Europe on the "Right" Path? Right-wing Extremism and Right-wing Populism in Europe. Berlin: Friedrich Ebert Stiftung.

Minkenberg, Michael 200I. "The Radical Right in Public Office. Agenda-setting and Policy Effects", West European Politics, 24, 4, s. I-2I. DOI: http://dx.doi.org/Io.IO80/OI402380I08425462

Mudde, Cas 2004. "The Populist Zeitgeist", Government and Opposition, 39, 4, s. 542-563. DoI: http://dx.doi.org/I0.IIII/j.I477-7053.2004.00I35.x

Mudde, Cas 2007. Populist Radical Right Parties in Europe. Cambridge: Cambridge University Press.

Mudde, Cas 2010. "The Populist Radical Right. A Pathological Normalcy", West European Politics, 33, 6, s. II67-II86 (en tidigare version av denna artikel finns i sv. övers. som "Den populistiska radikalhögern. En patologisk normalitet" i Fronesis nr 34 20IO).

DOI: http://dx.doi.org/IO.IO80/OI402382.20I0.50890I 
Ruzza, Carlo \& Fella, Stefano 2009. Re-inventing the Italian Right. Territorial Politics, Populism and "Post-fascism". London: Routledge.

Rydgren, Jens 2008. "France: The Front National, Ethnonationalism and Populism", i Albertazzi, Daniele \& McDonnell, Duncan (red.) Twenty-first Century Populism. The Spectre of Western European Democracy. Basingstoke: Palgrave Macmillan.

Schain, Martin A. 2006. "The Extreme-right and Immigration Policy-making. Measuring Direct and Indirect Effects", West European Politics, 29, 2, s. 270-289.

DoI: http://dx.doi.org/I0.I080/0I4023805005126I9

Schain, Martin A. 2009. "The State Strikes Back. Immigration Policy in the European Union", European Journal of International Law, 20, I, s. 93-I09. Dor: http://dx.doi.org/Io.IO93/ejil/chpoor

Schulz, Martin 20II. "Combating Right-wing Extremism as a Task for European Policy Making”, i Langenbacher, Nora \& Schellenberg, Britta (red.) Is Europe on the "Right" Path? Right-wing Extremism and Right-wing Populism in Europe. Berlin: Friedrich Ebert Stiftung.

Semyonov, Moshe, Raijman, Rebeca \& Gorodzeisky, Anastasia 2006. "The Rise of Anti-foreigner Sentiment in European Societies, 1988-2000", American Sociological Review, 7I, 3, s. 426-449.

DOI: http://dx.doi.org/I0.II77/000312240607100304

Spanje, Joost van 20I0. "Contagious Parties. Anti-immigration Parties and their Impact on other Parties' Immigration Stances in Contemporary Western Europe", Party Politics, I6, 5, s. 563-586.

DOI: http://dx.doi.org/I0.1177/1354068809346002

Sprague-Jones, Jessica 20II. "Extreme Right-wing Vote and Support for Multiculturalism in Europe", Ethnic and Racial Studies, 34, 4, s. 535-555. DoI: http://dx.doi.org/I0.I080/oI419870.20I0.512665

Stabenow, Michael 20Io. "EU-Ratspräsident Van Rompuy. Anlaufstelle für Merkel und Sarkozy", i Frankfurter Allgemeine Zeitung, 9 april 2010.

URL: http://www.faz.net/aktuell/politik/europaeische-union/eu-ratspraesident-vanrompuy-anlaufstelle-fuer-merkel-und-sarkozy-1965888.html (5 februari 2016)

Szczerbiak, Aleks \& Taggart, Paul (red.) 2008. Opposing Europe? The Comparative Party Politics of Euroscepticism. 2 vol. Oxford: Oxford University Press.

Tarchi, Marco 2008. "Italy: A Country of Many Populisms", i Albertazzi, Daniele \& McDonnell, Duncan (red.) Twenty-first Century Populism. The Spectre of Western European Democracy. Basingstoke: Palgrave Macmillan.

Van Dijk, Jan m.fl. 2006. The Burden of Crime in the EU. Research Report: A Comparative Analysis of the European Survey of Crime and Safety (EU ICS) 2005. Turin: UNICRI. URL: http://vorige.nrc.nl/redactie/binnenland/Misdaad.pdf ( 5 februari 20I6)

Westin, Charles 2003. "Racism and the Political Right. European Perspectives", i Merkl, Peter H. \& Weinberg, Leonard (red.) Right-wing Extremism in the Twenty-first Century. London: Frank Cass.

Wilkes, Rima, Guppy, Neil \& Farris, Lily 2007. "Right-wing Parties and Anti-foreigner Sentiment in Europe", American Sociological Review, 72, 5, s. 83I-840. DOI: http://dx.doi.org/IO.II77/000312240707200509 
Williams, Michelle Hale 2006. The Impact of Radical Right-wing Parties in West European Democracies. New York: Palgrave Macmillan.

Wlezien, Christopher 1995. "The Public as Thermostat: Dynamics of Preferences for Spending", American Journal of Political Science, 39, 4, s. 98I-Iooo.

DOI: http://dx.doi.org/I0.2307/2111666

Zakaria, Fareed 1997. "The Rise of Illiberal Democracy”, Foreign Affairs, 76, 6, s. 22-43. URL: https://www.foreignaffairs.com/articles/I997-II-OI/rise-illiberal-democracy (5 februari 20I6)

Zaslove, Andrej 2004. "Closing the Door? The Ideology and Impact of Radical Right Populism on Immigration Policy in Austria and Italy", Journal of Political Ideologies, 9, I, s. 99-II8.

DOI: http://dx.doi.org/I0.I080/1356931032000I67490 


\section{FÖRNUFTETS}

BANEMÄN

Från Nietzsche till Hitler

\section{Georg Lukács}

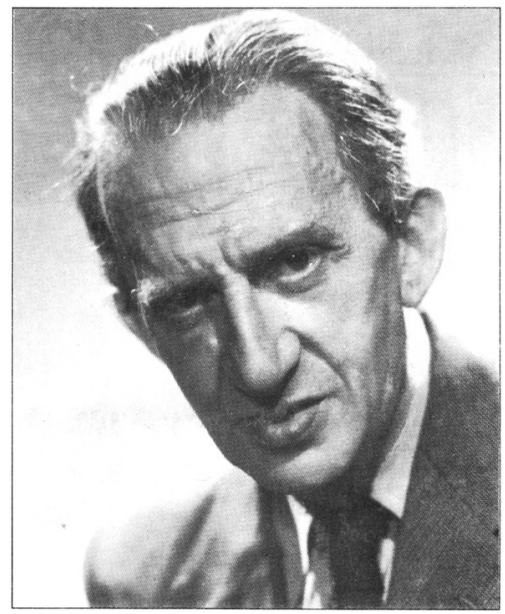

Georg Lukács omskrivna och omstridda frontalangrepp på den tyska filosofiska reaktionen och irrationalismen från 1954, Zerstörung der Vernunft, är fortfarande fascinerande läsning. Med utgångspunkt i devisen "Det finns ingen oskyldig världsåskådning” gör Lukács upp med den intellektuella miljö i Tyskland som han själv som ung befunnit sig i, och som han ansåg bidrog till att bereda vägen för Hitler och nazismen.

Arkiv förlag 1985, inbunden, 320 sidor

Fler böcker av Georg Lukács från Arkiv förlag:

Realismens seger. Litteraturkritiska essäer, Arkiv förlag 1983

Historia och klassmedvetande, Cavefors 1971 (i distribution) 